\title{
Local Toll-like receptor-mediated mast cell activation inhibits melanoma growth
}

\author{
SA Oldford ${ }^{1,2^{*}}$, ID Haidl ${ }^{1,2}$, MA Howatt ${ }^{1,2}$, CA Leiva $^{1,2}$, B Johnston ${ }^{1,2,3}$, JS Marshall ${ }^{1,2}$ \\ From Canadian Society of Allergy and Clinical Immunology Annual Scientific Meeting 2009 \\ Halifax, Canada. 22-25 October 2009
}

Mast cells are abundant at the periphery of the majority of solid tumors where they typically promote angiogenesis and enhance tumor growth. However, there is some evidence from epidemiological studies that allergic disease reduces cancer risk. In the context of infection, mast cell activation with Toll-like receptor (TLR) agonists induces the production of multiple mediators which mobilize and activate known anti-tumor effector cells. TLR agonists can also be effective in tumor immunotherapy. We demonstrate that the TLR2 agonist $\mathrm{Pam}_{3} \mathrm{CSK}_{4}$ is tumor inhibitory and mediates its effects via mast cell activation and reversal of the normal protumorigenic activity of mast cells. TLR2 agonist treatment decreased B16.F10 tumor growth in wild-type mice, but not in mast cell deficient Kit ${ }^{W-s h / W-s h}$ mice. Tumor growth inhibition following TLR2 agonist administration was restored in Kit ${ }^{W-s h / W-s h}$ mice by local reconstitution with wild-type, but not TLR2-deficient mast cells. Mast cell dependent tumor growth inhibition occurred independently of tumor necrosis factor (TNF) production and was not associated with direct tumor cytotoxicity or degranulation in vitro. Tumor growth inhibition was associated with mast cell dependent recruitment of natural killer (NK) and T cells. This study demonstrates that local mast cell activation provides a novel opportunity to modify the tumor microenvironment for successful cancer immunotherapy. Supported by the CCSRI and CIHR. S.A.O is a recipient of support from the Nova Scotia Health Research Foundation.

\section{Author details}

'Dalhousie Inflammation Group, Canada. ${ }^{2}$ Department of microbiology and Immunology, Dalhousie University, Halifax, NS, Canada. ${ }^{3}$ Department of pediatrics, Dalhousie University, Halifax, NS, Canada.

\footnotetext{
* Correspondence: sharon.oldford@dal.ca

'Dalhousie Inflammation Group, Canada
}

Published: 12 May 2010

doi:10.1186/1710-1492-6-S1-P19

Cite this article as: Oldford et al: Local Toll-like receptor-mediated mast cell activation inhibits melanoma growth. Allergy, Asthma \& Clinical

Immunology 2010 6(Suppl 1):P19.
Submit your next manuscript to BioMed Central and take full advantage of:

- Convenient online submission

- Thorough peer review

- No space constraints or color figure charges

- Immediate publication on acceptance

- Inclusion in PubMed, CAS, Scopus and Google Scholar

- Research which is freely available for redistribution

Submit your manuscript at www.biomedcentral.com/submit
C Biomed Central 